\title{
EVALUASI PELAKSANAAN PEMBELAJARAN MODEL TEACHING FACTORY DALAM UPAYA PENINGKATAN MUTU LULUSAN
}

\author{
Novrian Satria Perdana \\ Pusat Penelitian Kebijakan Pendidikan dan Kebudayaan \\ Email: novrian1711@gmail.com
}

\begin{abstract}
ABSTRAK
Hingga agustus 2018 angka pengangguran SMK 24,74\% dari total pengangguran terbuka sebesar 7,069 juta. Hal ini mengindikasikan bahwa antara materi pembelajaran di SMK belum sesuai dengan kebutuhan dunia kerja, sehingga diperlukan upaya peningkatan mutu, relevansi dan revitalisasi pendidikan SMK dalam membentuk SDM yang berkualitas, berdaya saing tinggi. Dengan demikian tercipta link and match antara pembelajaran di sekolah dengan kebutuhan dunia usaha/dunia industri (DU/DI). Dalam upaya menciptakan link and match antara SMK dengan dunia industri, maka Pemerintah menyusun model pembelajaran berbasis teaching factory. Model pembelajaran tersebut sudah berjalan sehingga perlu dilakukan evaluasi pelaksanaannya. Berdasarkan hal tersebut maka tujuan penelitian ini adalah untuk menganalisis evaluasi pelaksanaan pembelajaran model teaching factory di SMK dalam upaya peningkatan mutu lulusan. Dalam penelitian ini menggunakan pendekatan kualitatif dengan metode analisis data sekunder dan survey. Fokus penelitian penelitian yaitu capaian pelaksanaan pembelajaran model teaching factory di SMK bidang Pariwisata Provinsi Sumatera Utara tahun 2018. Kesimpulan dari penelitian ini adalah (1) model pembelajara teaching factory efektif meningkatkan motivasi siswa untuk mengikuti kegiatan pembelajaran dan berdampak positif bagi peningkatan kualitas hasil evaluasi siswa, dan (2) model pembelajaran teaching factory dengan unit produksi yang ada dapat menghasilkan produk/jasa yang layak jual sehingga dapat menambah penghasilan sekolah yang dapat digunakan untuk membantu biaya operasional sekolah serta dapat digunakan sebagai media promosi sekolah kepada masyarakat.
\end{abstract}

Kata Kunci: Teaching Factory, SMK, Pembelajaran

\section{PENDAHULUAN}

Sumber Daya Manusia (SDM) merupakan aset utama dalam membangun suatu bangsa. Ketersediaan sumber daya alam (natural resources) yang melimpah dan adanya sumber daya modal serta teknologi yang semakin canggih, tidak akan mempunyai kontribusi yang bernilai tambah, tanpa didukung oleh adanya sumber daya manusia (human resources) yang berkualitas. Dengan jumlah SDM yang besar terutama yang memiliki kompetensi dan memiliki produktivitas tinggi, maka negara dapat mencapai pertumbuhan optimal dan juga memiliki nilai competitiveness lebih dibanding negara lainnya yang tentunya sangat penting terutama di era globalisasi seperti saat ini. 
Berkaitan dengan daya saing Indonesia, berdasarkan data yang bersumber dari World Economic Forum (2018) pada tahun 2018 Global Competitiveness Index Indonesia berada di peringkat 45 jauh di bawah sesama negara ASEAN, yaitu Singapura peringkat 7, Malaysia peringkat 21 dan Thailand peringkat 28. Khusus untuk pilar ke-6 tentang skills, Indonesia berada di peringkat 62, juga masih kalah dibandingkan dengan Negara Singapura (20), dan Malaysia (24), namun sudah unggul dengan Thailand (66). Kondisi ini menunjukkan bahwa berbagai komoditi Indonesia kurang berdaya saing di pasar global termasuk SDMnya. Daya saing merupakan sekumpulan intuisi, kebijakan, dan faktor yang menentukan tingkat produktivitas dari suatu negara.

Dunia pendidikan merupakan sumber utama dalam penyediaan tenaga kerja (SDM) yang kompeten di pasar kerja. Namun masih ada gap antara kebutuhan SDM di industri dengan SDM yang dihasilkan oleh lembaga pendidikan. Ancaman lain adalah akan ada serbuan tenaga kerja asing ke negara ini jika semua pintu globalisasi telah dibuka. Implikasinya dalam pengembangan SDM adalah walaupun hanya untuk memenuhi kebutuhan lokal namun kualitas tetap dituntut untuk memenuhi standar global agar tetap mampu bersaing dan tidak tersisih di negeri sendiri.

Sejalan dengan program peningkatan SDM, Pendidikan Nasional khususnya pendidikan kejuruan penting memberikan kontribusi dalam mempersiapkan SDM yang terampil dan memiliki daya saing tinggi. Pendidikan kejuruan memiliki tujuan mencetak SDM lulusan SMK yang berkompeten yang siap terjun kedunia industri serta memiliki kemampuan untuk menciptakan lapangan kerja sendiri. Direktorat Jendral Manajemen Pendidikan Dasar dan Menengah, mengemukakan bahwa upaya penerimaan lulusan SMK di dunia kerja atau industri dapat dilakukan dengan cara: (a) memperkuat kemampuan adaptif yang meliputi kemampuan matematika terapan dan sains terapan, (b) memperkuat kemampuan berwirausaha, (c) memperkuat kemampuan menggunakan berbahasa nasional dan internasional, (d) memperkuat kemampuan dasar TIK, (e) melaksanakan teaching factory (Direktorat PSMK, 2010). 
Menurut Badan Pusat Statistik (BPS) Agustus 2018 angka pengangguran SMK 24,74\% dari total pengangguran terbuka sebesar 7,069 juta. Selain banyaknya angka pengangguran lulusan SMK, secara kualitas juga masih kurang. Berkaitan dengan kualitas lulusan, berdasarkan data hasil Ujian Nasional (UN) SMK tahun 2017/2018 pada gambar 1 di bawah ini, secara keseluruhan rata-rata hasil UN SMK tahun 2017/2018 untuk Nasional memiliki nilai 45,20. Dan diantara 34 Provinsi yang memiliki rata-rata UN tahun 2017/2018 di atas ratarata Nasional hanya ada 10 Provinsi. Hasil ini mengindikasikan kualitas lulusan SMK masih kurang dan belum merata di seluruh wilayah.
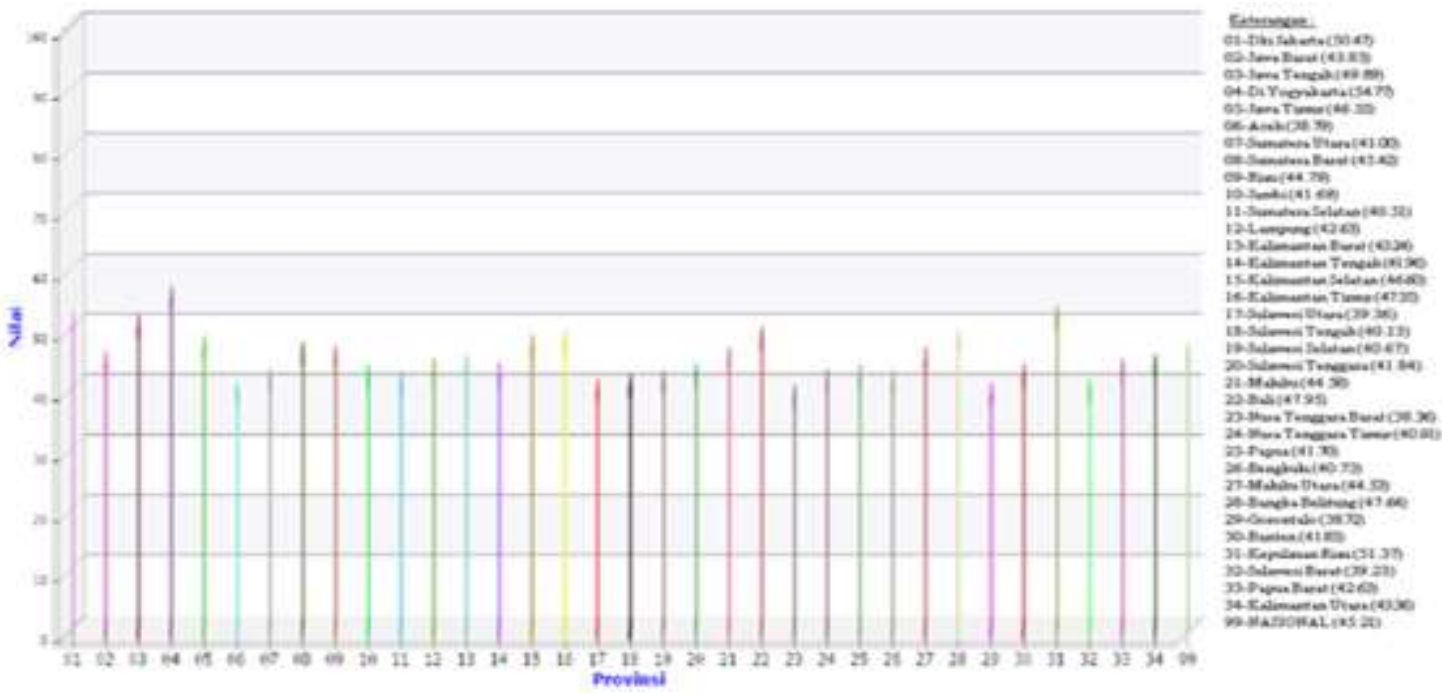

Sumber: Puspendik, 2018

\section{Gambar 1. Rata-rata Nilai Ujian Nasional SMK (Negeri dan Swasta) Tahun 2017/2018}

Sekolah Menengah Kejuruan diharapkan dapat menekan angka pengangguran, sekaligus memberikan kontribusi menghasilkan SDM untuk memenuhi kebutuhan SDM global. Sekolah Menengah Kejuruan (SMK) dituntut membentuk peserta didik yang memiliki kemampuan soft skill dan hard skill yang baik, meningkatkan proses kualitas pembelajaran khususnya dalam bidang praktik. Menurut Hamidah (2018), peserta didik dalam pemaknaan regulasi adalah anggota masyarakat yang berusaha mengembangkan potensi diri melalui proses pembelajaran yang tersedia pada jalur, jenjang, dan jenis pendidikan tertentu. Kompetensi yang diperoleh peserta didik pada saat pembelajaran teori dapat dipraktikkan 
semaksimal mungkin di bengkel (workshop) yang dimiliki. Dalam kenyataannya, sering terjadi ketidak sesuaian antara teori yang diperoleh dengan proses praktik yang dilakukan, bahkan hasil yang dipelajari di sekolah baik teori maupun praktik berbeda dengan kondisi yang ada di dunia kerja. Saat ini, masih terjadi miss match antara yang dipelajari di sekolah dengan kebutuhan kualifikasi dunia usaha dan industri. Artinya, antara materi pembelajaran di SMK belum sesuai dengan kebutuhan dunia kerja, sehingga diperlukan peningkatan mutu, relevansi dan revitalisasi pendidikan SMK dalam membentuk SDM yang berkualitas, berdaya saing tinggi. Dengan demikian tercipta link and match antara pembelajaran di sekolah dengan kebutuhan dunia usaha/dunia industri (DU/DI).

Dalam upaya menciptakan link and match antara SMK dengan dunia industri, maka Pemerintah menyusun model pembelajaran berbasis teaching factory. Di Indonesia, penerapan konsep teaching factory telah diperkenalkan di SMK pada tahun 2000 dalam bentuk yang sangat sederhana yaitu berupa pengembangan unit produksi yang sudah dilaksanakan di SMKSMK. Kemudian konsep tersebut berkembang pada tahun 2005 menjadi sebuah model pengembangan SMK berbasis industri. Terdapat tiga bentuk dasar kategori pengembangan SMK berbasis industri, yaitu: 1) Pengembangan SMK berbasis industri sederhana; 2) Pengembangan SMK berbasis industri yang berkembang dan; 3) Pengembangan SMK berbasis industri yang berkembang dalam bentuk factory sebagai tempat belajar. Kemudian selanjutnya pada awal tahun 2011 pengembangan SMK dengan model yang ketiga, yaitu pengembangan SMK berbasis industri yang berkembang dalam bentuk factory sebagai tempat belajar, selanjutnya dikenal dengan teaching factory. Factory di sini hanyalah istilah dan bukan arti pabrik secara harafiah, namun dalam bentuk pembelajaran dilakukan langsung di tempat praktik tidak di dalam kelas, dan praktik yang dilakukan berorientasi pada produksi seperti di industri nyata. Penyelenggaraan model ini memadukan sepenuhnya antara belajar dan bekerja, tidak lagi memisahkan antara tempat penyampaian teori dan praktik. Menurut Kuswantoro dalam Fuadi (2016) teaching factory merupakan pembelajaran berorientasi bisnis dan produksi. Proses penerapan program teaching factory adalah dengan memadukan konsep bisnis dan pendidikan kejuruan sesuai dengan kompetensi keahlian yang relevan, misalnya 
pada program studi keahlian tata busana melalui kegiatan pembuatan dan penjualan busana yang dikerjakan oleh Peserta Didik.

Pada tahun 2011, Direkorat Pembinaan SMK bekerja sama dengan pemerintah Jerman melalui program Technical and Vocational Education and Training (TVET) mengembangkan konsep teaching factory. Sekolah Menengah Kejuruan (SMK) dituntut membentuk siswa yang memiliki kemampuan soft skill dan hard skill yang baik, meningkatkan proses kualitas pembelajaran khususnya dalam bidang praktik. Kompetensi yang diperoleh siswa pada saat pembelajaran teori dapat dipraktikkan semaksimal mungkin di bengkel (workshop) yang dimiliki. Dalam kenyataannya, sering terjadi ketidak sesuaian antara teori yang diperoleh dengan proses praktik yang dilakukan, bahkan hasil yang dipelajari di sekolah baik teori maupun praktik berbeda dengan kondisi yang ada di dunia kerja.

Pendidikan kejuruan memiliki peranan penting dalam upaya mencetak tenaga kerja yang memiliki kompetensi yang sesuai dengan karakteristik kebutuhan dunia industri. Model teaching factory merupakan salah satu solusi untuk menyiapkan peserta didik agar memiliki kompetensi yang sesuai dengan kebutuhan kompetensi dunia industri. Pembelajaran teaching factory yang dikembangkan dapat di integrasikan pada unit produksi yang diselenggarakan oleh sekolah (Nurtanto, dkk, 2017). Pembelajaran teaching factory adalah suatu konsep pembelajaran di SMK berbasis produksi/jasa yang mengacu kepada standar dan prosedur yang berlaku di industri, dan dilaksanakan dalam suasana seperti yang terjadi di industri. Hal ini sesuai karakteristik pendidikan kejuruan seperti yang disebutkan Herminarto Sofyan (2008). yaitu: (1) mempersiapkan peserta didik memasuki lapangan kerja; (2) didasarkan kebutuhan dunia kerja "demand-market-driven"; (3) penguasaan kompetensi yang dibutuhkan dunia kerja; (4) kesuksesan siswa pada "hands on" atau performa dunia kerja; (5) hubungan erat dengan dunia kerja; (6) responsif dan antisipatif terhadap kemajuan teknologi; (7) learning by doing dan Vocational Education and Training (TVET) di negara Jerman dan Swiss. Metode pembelajaran dual system merupakan metode yang mengintegrasikan dua lingkungan utama dalam setiap kegiatan peserta didik, yakni lingkungan sekolah dan lingkungan perusahaan (industri). Peserta didik tidak hanya melakukan kegiatan belajar di sekolah, tetapi juga 
melakukan praktik (kompetensi dasar) dan kerja (mengaplikasikan kompetensinya) di industri dalam jangka waktu yang relatif panjang. Secara fundamental, dual system bertujuan untuk menempatkan peserta didik dalam situasi nyata di tempat kerja secara menyeluruh. Dengan praktik yang demikian, peserta didik tidak hanya memperoleh pengetahuan teoritis, tetapi juga mampu menerapkan praktik berbasis produksi sebagaimana diterapkan dalam kegiatan industri. Hal ini membuat peserta didik memperoleh keterampilan, proses dan sikap yang sesuai dengan standar industri sehingga kompetensi pendidikan sesuai dengan kebutuhan industri.

Pembelajaan teaching factory diharapkan menghasilkan lulusan yang sesuai dengan kebutuhan dunia usaha dan dunia industri (DUDI). Penyerapan tenaga kerja oleh institusi secara kualitatif masih terpaut jauh dari kapasitas daya tampung industri setiap tahunnya, meskipun celah angka jumlah lulusan (supply) dengan angka jumlah permintaan (demand) tidak terlalu lebar. Permasalahan yang dihadapi oleh salah satunya yaitu kesenjangan capaian kompetensi para lulusan institusi pendidikan dan pelatihan kejuruan. Teaching factory mengintegrasikan proses pembelajaran untuk menghasilkan produk maupun jasa yang layak jual untuk menghasilkan nilai tambah untuk sekolah (Direktorat Pembinaan SMK, 2010). Artinya, proses teaching factory dapat menanamkan jiwa kewirausahaan bagi siswa. Melalui proses teaching factory menghasilkan produk barang dan jasa yang memiliki nilai tambah dengan kualitas yang bisa diserap dan diterima oleh masyarakat. Ciri yang dimiliki sekolah yang menjalankan teaching factory, yaitu sarana dan prasarana yang dimiliki di sebuah sekolah 60-70\% dipergunakan untuk kegiatan produksi, kegiatan bisnis yang dilakukan hanya operasional bisnis dan produksi, dan pendapatan yang dimiliki tersebut berbeda dengan ciri sekolah yang melaksanakan pendidikan berbasis produksi dimana 90\% sarana dan prasarana yang dimiliki dipergunakan untuk kegiatan produksi, proses bisnis yang dilakukan lengkap dengan pendukung bisnis dan pendapatan yang dihasilkan mampu untuk menutup pembiayaan operasional sekaligus sebagai investasi (Triatmoko, 2009). Penyelenggaraan model teaching factory memadukan sepenuhnya antara belajar dan bekerja, tidak lagi memisahkan antara tempat penyampaian materi teori dan tempat materi produksi (praktik). Bentuk organisasi 
teaching factory menunjukkan sifat dari perusahaan, tenaga pengajar merupakan kelompok profesional dalam bidang pendidikan yang diharapkan yang mampu memenuhi kebutuhan masyarakat atas produk dan jasa sesuai dengan kelompok SMK.

Hingga saat ini ada beberapa penelitian yang mengevaluasi efektifitas teaching factory, diantaranya yang dilakukan oleh Fajaryati, 2012. Penelitian ini merupakan penelitian deskriptif dengan pendekatan evaluasi model formatif-sumatif oleh Scriven yang menekankan pada evaluasi formatif. Populasi penelitian adalah semua SMK di Surakarta yang menjalankan teaching factory berjumlah 9 sekolah dan respondennya adalah 81 guru pengampu kompetensi keahlian yang menjalankan teaching factory di sekolah tersebut. Hasil penelitian menunjukkan bahwa pelaksanaan teaching factory SMK di Surakarta ditinjau dari kegiatan pembelajaran dinyatakan sangat baik $(17,28 \%)$ oleh 14 guru, baik $(39,51 \%)$ oleh 32 guru, tidak baik $(25,93 \%)$ oleh 21 guru, dan sangat tidak baik $(17,28 \%)$ oleh 14 guru. Sedangkan hasil pelaksanaan teaching factory SMK di Surakarta ditinjau dari proses produksi dinyatakan sangat baik $(14,81 \%)$ oleh 12 guru, baik $(27,16 \%)$ oleh 22 guru, tidak baik $(44,44 \%)$ oleh 36 guru, dan sangat tidak baik $(13,58 \%)$ oleh 11 guru.

Penelitian berikutnya dilakukan oleh Haris, 2012. Hasil penelitian ini adalah; 1). Pengelolaan pendidikan di SMK Muhammadiyah 1 Klaten dalam meningkatkan pelayanan kepada stake holder telah berupaya dengan menerapkan pembelajaran berbasis teaching factory dengan baik, 2).Para guru di SMK Muhammadiyah 1 Klaten telah melakukan proses pembelajaran berbasis teaching factory dengan mempertimbangkan beberapa hal, yaitu, membangun karakter guru yang kuat, merencanakan pembelajaran melalui lembar kerja dan melakukan pembelajaran berbasis kebutuhan industri atau konsumen, 3) Dalam melaksanakan proses pembelajaran berbasis teaching factory siswa telah di siapkan sejak awal untuk memiliki kemampuan dan kepribadian yang baik, serta membekali mereka dengan beberapa kompetensi agar siswa kelak setelah lulus mereka siap kerja maupun menjadi wirausaha mandiri.

Penelitian serupa juga pernah dilakukan oleh Indahsari, 2017. Tujuan penelitian ini adalah untuk mengevaluasi pelaksanaan model pembelajaran Teaching Factory pada mata 
pelajaran produktif dan proses produksi Air Minum Dalam Kemasan (AMDK). Metode penelitian yang digunakan adalah penelitian evaluatif dengan menggunakan model evaluasi CIPP (Context, Input, Process, dan Product). Subjek penelitian ini adalah semua pihak yang terlibat dalam Teaching Factory, yaitu kepala sekolah, penanggung jawab Teaching Factory bidang produksi AMDK, guru mata pelajaran produktif Dasar Pengendalian Mutu, dan siswa kelas XII TPHP Jurusan Teknologi Pengolahan Hasil Pertanian SMK Negeri 2 Subang. Hasil penelitian diketahui bahwa (1) pelaksanaan Teaching Factory ditinjau dari komponen Context terlaksana hingga 100\% sesuai ketentuan, terkait dukungan sekolah dan dampak Teaching Factory terhadap sekolah, (2) pelaksanaan Teaching Factory ditinjau dari komponen Input terlaksana hingga 50\% sesuai ketentuan, dengan memerlukan perbaikan yang menitikberatkan pada persiapan pembelajaran dan penjadwalan, (3) pelaksanaan Teaching Factory ditinjau dari komponen Process terlaksana hingga 53,8\% sesuai dengan ketentuan, dengan memerlukan perbaikan yang menitikberatkan pada kegiatan pengawasan mutu, manajemen MRC, dan pelaksanaan berbasis corporate culture pada pelaksanaan Teaching Factory, (4) pelaksanaan Teaching Factory ditinjau dari komponen Product terlaksana hingga 75\% sesuai ketentuan, menunjukkan bahwa model pembelajaran Teaching Factory mampu meningkatkan kompetensi dan keahlian siswa dan menghasilkan produk air minum yang baik.

Teaching factory sudah dilaksanakan sejak lama, namun sampai saat perlu dikaji lebih dalam sampai sejauhmana efektifitasnya dalam upaya meningkatkan mutu lulusan. Berkaitan dengan hal tersebut penulis melakukan penelitian dengan judul "Evaluasi Pelaksanaan Pembelajaran Model Teaching Factory Dalam Upaya Peningkatan Mutu Lulusan”. Adapun tujuan penelitian untuk menganalisis evaluasi pelaksanaan pembelajaran model teaching factory di SMK.

\section{METODE}

Dalam penelitian ini menggunakan pendekatan kualitatif dengan metode analisis data sekunder dan survey. Data sekunder bersumber dari data statistik yang diterbitkan oleh Badan Pusat Statistik dan Kementerian Pendidikan dan Kebudayaan terkait dengan data input dan 
output sistem pendidikan, seperti kualitas lulusan SMK, data guru, sarana-prasarana, pembiayaan pendidikan, dan sebagainya. Sedangkan data primer diperoleh dari survei sekolah khususnya terkait dengan pengelolaan sekolah berasrama. Di samping itu, dalam penelitian ini juga digunakan pendekatan kualitatif dengan teknik Focus Group Discussion (FGD) dan wawancara kepada sejumlah narasumber (informan) di provinsi Sumatera Utara. Unit analisis dalam penelitian ini adalah SMK Negeri di Provinsi Sumatera Utara bidang Pariwisata.

Fokus penelitian penelitian yaitu capaian pelaksanaan pembelajaran model teaching factory di SMK sampel. Untuk memperoleh informasi hal tersebut, sejumlah nara sumber pengambil keputusan di bidang pendidikan di provinsi Sumatera Utara digunakan sebagai informan, seperti Kepala Dinas Pendidikan, dan/atau pejabat yang mewakilinya di tingkat provinsi, Kepala SMK, dan Dunia Usaha rekanan.

\section{PEMBAHASAN HASIL PENELITIAN}

Kondisi ideal implementasi teaching factory di SMK, meliputi aspek-aspek dan sub aspek sebagai berikut: 1. Aspek Pembelajaran Bahan ajar mempunyai tujuan untuk mencapai kompetensi tertentu dan merupakan sesuatu yang multiguna (marketable), khusus untuk program kompetensi yang tidak menghasilkan produk/jasa dapat diarahkan pada simulasi dari situasi kerja riil di lapangan, sistem penilaian yang digunakan sudah berbasis teaching factory dan sistem pembelajaran menggunakan jadwal blok dan kontinyu. 2. Sumber Daya Manusia Sumber daya manusia mempunyai kemampuan design engineering dan dapat menerapkan sense of quality, sense of efficiency dan sense of innovation. Untuk proses kegiatan belajar harus memperhatikan rasio jumlah guru dan jumlah peserta didik. 3. Fasilitas Fasilitas yang dimiliki sekolah harus memenuhi rasio $1: 1$ antara peserta didik dan alat, penanganan perawatan sudah menerapkan MRC (Maintanance Repair and Calibration), untuk alat bantu proses sudah sesuai dan lengkap, seluruh peralatan di kembangkan terus menerus (penambahan dan penggantian alat). 4. Kegiatan Praktik Menerapkan budaya industri dengan adanya standar kualitas (quality control), target waktu, efisiensi proses produksi, rotasi kerja (shift), produk kerja yang jelas, hasil praktik dapat menjadi sumber pendapatan (generating 
income), fungsi dan tanggung jawab yang jelas untuk setiap penanggung jawab, lingkungan kerja dibuat dan dijaga sehingga jadi aman dan nyaman, kegiatan pembelajaran teratur dan lancar, kontrol dan pemantauan dilakukan secara terus menerus. 5. Jaringan Kerjasama (Network) Sekolah mempunyai network dengan industri, baik untuk transfer teknologi maupun membangun budaya industri di sekolah. 6. Produk dan Jasa Produk dan jasa yang dihasilkan sudah sesuai dengan standar industri. 7. Transparansi, pencatatan transaksi keuangan sudah sesuai dengan standar prosedur akuntansi (tata kelola keuangan). 8. Aspek legal berupa peraturan harus tersedia untuk penyelenggaraan teaching factory.

Hasil kajian pelaksanaan teaching factory di Provinsi Jawa Tengah yang meliputi aspek perencanaan Tefa, pelaksanaan pembelajaran, kegiatan produksi/jasa, kerjasama industri, dampak program, kendala yang dihadapi, dan tefa sebagai strategi pendanaan SMK, disampaikan sebagai berikut.

\section{Perencanaan Teaching Factory (tefa)}

Pelaksanaan tefa di SMK cukup variatif, umumnya sudah direncanakan dengan mengidentifikasi kekuatan dan kelemahan terkait dengan sumberdaya, sarana dan unit produksi yang ada. Perencanaan Tefa umumnya belum mengacu sepenuhnya pada panduan pelaksanaan Tefa Direktorat Pembinaan SMK. Hal ini dikarenakan belum semua SMK memahami Tefa. Dari hasil diskusi baru 50\% pemahaman SMK terhadap Tefa, namun hal ini tidak mengurangi semangat untuk melaksanakan Tefa di SMK. Semangat untuk memhami Tefa beberapa SMK mengundang nara sumber dari SMK lain yang telah memahami tefa. Dalam merencanakan Tefa di SMK umumnya direncakan antara kepala sekolah dan guru-guru, belum melibatkan industri dalam perencanaannya. Pelaksaan Tefa umumnya sangat dipengaruhi oleh kepemimpinan kepala sekolah dan juga keberadaan guru-guru produktif yang mempunyai komitmen terhadap kemajuan sekolah dan mempunyai jiwa interpreneur.

Program keahlian yang dikembangkan melalui Model teaching factory di SMK pariwisata bervariasi antar SMK, belum semua program keahlian yang terdapat di SMK pariwisata dikembangkan menjadi dalam teaching factory. Hal ini terkait dengan kondisi 
sekolah, keberadaan DUDI, wilayah, sarana, dan kesiapan tenaga pendidik program keahlian yang ada di SMK. Kompetensi keahlian yang sudah dikembangkan menjadi model teaching factory antara lain; akomodasi perhotelan (edotel), tata boga, tata kecantikan, tata busana, dan usaha perjalanan wisata.

Struktur organisasi sebagai bentuk tanggungjawab pelaksanaan kegiatan seharihari sesuai dengan tugas dan fungsi masing-masing. Susunan organisasi secara umum terdiri dari ketua, sekretaris, bendahara, dan koordinator produksi/jasa. Struktur yang dibuat umumnya belum selengkap sebagaimana panduan tefa yang sudah memasukkan penanggung jawab produksi, pemasaran, dan pemastian kualitas. Untuk prosedur kerja umumnya sudah ada yang dipasang pada ruang praktik. Bentuk payung hukum pengelolaan tefa di SMK cukup bervariasi, ada yang belum mempunyai bentuk hukum, bentuk koperasi, dan badan layanan umum daerah (BLUD).

Pencatatan keuangan hasil tefa pada masing-masing program keahlian sebagaian besar sudah dicatat secara tersendiri, oleh koordinator unit produksi/jasa berdasarkan program keahlian yang ada, dan hasil keuntungan sudah dapat digunakan untuk biaya operasional seperti pembelian bahan praktik, servis ringan, investasi alat dan sebagain kecil sudah dapat untuk membayar listrik dan telepon.

\section{Pelaksanaan Pembelajaran}

Kurikulum yang digunakan sebagian besar menggunakan kurikulum 2013, namun masih ada yang belum melakukan penyesesuaian dengan kebutuhan industri. Hanya sekitar 30\% SMK yang telah bekerjasama dengan industri dalam penyusunan kurikulum secara bersama yaitu untuk kelas khusus industri. Untuk rencana pelaksanaan pembelajaran (RPP) umumnya disusun dengan mengacu pada kompetensi dasar dan kompetensi inti berdasarkan muatan kurikulum seperti kegiatan pembelajaran pada umumnya. Penyusunan RPP belum berdasarkan serangkaian analisis kebutuhan pembelajaran tefa, seperti analisis standar kompetensi, analisis pembelajaran berbasis produksi, jadwal pembelajaran produktif, pelaksanaan produksi, dan penanganganan produk. 
Untuk guru-guru mapel produktif di SMK secara kualifikasi sudah cukup baik dan sebagian besar sudah sesuai dengan program keahlian yang diampunya. Hanya saja jumlah guru produktif rata-rata masih kurang, demikian pula guru-guru yang berpengalaman industri. Untuk mengatasi kekurangan guru-guru produktif di beberapa SMK telah ditambah dengan guru-guru keahlian ganda dan guru honorer.

\section{Kegiatan Produksi/jasa}

Kegiatan produksi/jasa yang dikaji meliputi aspek peralatan praktik, rasio siswa dan alat, frekuensi praktik, dan produk yang dihasilkan. Dari aspek peralatan praktik di masing-masing program keahlian umumnya sudah cukup baik, terutama untuk program keahlian akomodasi perhotelan, tata boga dan tata busana. Adapun pengadaan peralatan praktik bersumber dari dana BOS dan bantuan Pemda. Sementara untuk program keahlian usaha perjalanan wisata umumnya masih kurang. Hasil produk/jasa pelaksanaan Tefa di SMK sampel kondisinya juga bervariasi, hal ini terkait dengan kondisi peralatan yang ada. Dari aspek peralatan (sarana-prasarana), hampir semua program keahlian rata-rata sudah cukup baik, hanya ada beberapa yang sarana masih kurang. Untuk program keahlian akomodasi perhotelan, tata boga, tata busana, dan tata kecantikan rata-rata sudah cukup baik, sementara untuk program usaha perjalanan wisata rata-rata masih kurang.

Untuk hasil produk/jasa yang sudah cukup baik umumnya dari akomodasi perhotelan, tata boga, dan tata busana. Hasil produk/jasa dari ketiga program keahlian ini umumnya sudah sudah berstandar industri dan layak untuk dipasarkan. Hasil penjualan produk/jasa sudah dapat membantu biaya opersional sekolah minimal untuk pembelian bahan praktik. Sementara untuk tata kecantikan dan usaha perjalanan wisata rata-rata belum berkontribusi terhadap biaya operasional sekolah.

\section{Kerjasama Industri}

Kerjasama antara SMK dan industri dalam pelaksanaan model Tefa sangat diperlukan, hal ini terkait dengan pelaksanaan kegiatan prakerin dan kegiatan magang 
guru-guru produktif. Kondisi kerjasama antara SMK dan industri umumnya sudah terjalin dengan baik, namun belum semua program keahlian telah bekerjasama dengan industri dengan jumlah yang cukup. Untuk program keahlian tata boga, tata busana, dan usaha perjalanan wisata umumnya masih terbatas. Banyaknya mitra industri juga terkait dengan usaha kepala sekolah dan guru dalam menjalin kerjasama.

\section{Dampak Program}

Dampak program teaching factory di SMK bidang pariwisata cukup efektif walaupun belum berjalan maksimal baik untuk siswa, guru, sekolah, dan masyarakat. Dampak bagi siswa adalah; 1) semangat belajar siswa makin meningkat karena kegiatan praktik yang dilakukan sudah menyerupai kegiatan nyata di industri. Hal ini terlihat dari tingkat kehadiran siswa ketika kegiatan praktik; 2) meningkatkan kompetensi dan percaya diri siswa; 3) menumbuhkan semangat jiwa enterpreneur; 4) meningkatkan mutu lulusan, indikasinya tingkat keterserapan di industri tinggi.

Dampak bagi guru kegiatan pembelajaran menjadi lebih menyenangkan karena kegiatan praktik sudah menyerupai industri yang dapat menghasilkan produk/jasa yang dapat dijual, sehingga guru dan siswa lebih semangat karena hasil praktik dapat dijual memudahkan untuk pembelian bahan sebagai alat praktik. Guru juga lebih semangat mengajar, karena memiliki kesempatan untuk meningkatkan kemampuannya pada saat praktikum, dan rasa kebanggaan terhadap prestasi siswa dari produk/jasa yang dihasilkan siswa.

Dampak bagi sekolah; bahwa model pembelajaran tefa dengan unit produksi yang ada dapat menghasilkan produk/jasa yang layak jual sehingga dapat menambah penghasilan sekolah yang dapat digunakan untuk membantu biaya operasional sekolah serta dapat digunakan sebagai media promosi sekolah kepada masyarakat.

Bagi masyarakat dapat ikut belajar keterampilan di SMK, serta menggunakan produk/jasa yang dihasilkan dari siswa SMK dengan biaya/harga yang lebih terjangkau.

\section{Kendala yang dihadapi}




\section{Jurnal Serunai Administrasi Pendidikan \\ Vol.7, No.1, Desember 2018 \\ e-ISSN 2620-9209}

Kendala yang dihadapi secara umum dalam pelaksanaan model teaching factory sebagai berikut: (1) Kurangnya SDM pengelola teaching factory (guru-guru mapel produktif) terutama terkait dengan pergantian personil (perpindahan dll); (2) kurangnya sarana peralatan praktik; (3) karakter siswa yang perlu terus ditingkatkan agar dapat melalyani/memproduksi produk standar industri. (3) Terbatasnya lahan untuk pelaksanaan Tefa, luas ruang praktik kurang, tidak dapat menyediakan tempat outlet untuk memamerkan produk, (4) Promosi/pemasaran yang masih terbatas pada kalangan tertentu; (5) Produk/jasa masih tergantung pesanan ; (6) Belum adanya payung hukum yang kuat dalam pelaksanaan Tefa, yang dapat membuat rasa aman kepala sekolah dan guru dalam pelaksanaan tefa di SMK sebagai model pembelajaran siswa yang dapat menghasilkan keuntungan atas penjualan/sewa produk/jasa.

\section{SIMPULAN}

Berdasarkan hasil diskusi, maka dapat disimpulkan sebagai berikut:

1. Model pembelajara teaching factory efektif meningkatkan motivasi siswa untuk mengikuti kegiatan pembelajaran dan berdampak positif bagi peningkatan kualitas hasil evaluasi siswa.

2. Model pembelajaran tefa dengan unit produksi yang ada dapat menghasilkan produk/jasa yang layak jual sehingga dapat menambah penghasilan sekolah yang dapat digunakan untuk membantu biaya operasional sekolah serta dapat digunakan sebagai media promosi sekolah kepada masyarakat.

\section{REFERENSI}

Badan Pusat Statistik. 2018. Data Pengangguran Terbuka Menurut Pendidikan Tertinggi yang Ditamatkan 1986 - 2018.

Direktorat PSMK. 2010. Tatakelola Pelaksanaan Teaching Factory. Direktorat Dikdasmen Kementerian Pendidikan dan Kebudayaan.

Fajaryati, Nuryake. 2012. Evaluasi Pelaksanaan Teaching Factory SMK Di Surakarta. Jurnal 
Pendidikan Vokasi, Vol 2, Nomor 3, November 2012

Fuadi, Afnan. 2016. Evaluasi Program Pembelajaran Teaching Factory Di Sekolah Usaha Perikanan Menengah. Jurnal Perspektif Ilmu Pendidikan - Vol. 30 No.2 Oktober 2016

Hamidah, 2018. Manajemen Peserta Didik. Jurnal Serunai Administrasi Pendidikan Vol.6, No.2, Juni 2018

Haris, Abdul. 2012. Pengelolaan Pembelajaran Berbasis Teaching Factory (Studi Situs SMK Muhammadiyah 1 Klaten). Magister Manajemen Pendidikan Program Pasca Sarjana Universitas Muhammadiyah Surakarta.

Herminarto Sofyan. 2008. Optimalisasi Pembelajaran Berbasis Kompetensi pada Pendidikan Kejuruan. Pidato Pengukuhan Guru Besar, disampaikan pada Rapat Terbuka Senat Universitas Negeri Yogyakarta, Sabtu 16 Februari 2008.

Indahsari, Euis Lise. 2017. Evaluasi Pelaksanaan Model Pembelajaran Teaching Factory Pada Pembelajaran Produktif TPHP. Universitas Pendidikan Indonesia.

Nurtanto, dkk. 2017. Pengembangan Model Teaching Factory di Sekolah Kejuruan. Prosiding Seminar Nasional Pendidikan FKIP UNTIRTA 2017.

Puspendik. 2018. Rata-rata Nilai Ujian Nasional SMK (Negeri dan Swasta) Tahun 2017/2018. Balitbang Kemendikbud.

Triatmoko, SJ. 2009. The ATMI story, rainbow of excellence. Surakarta: ATMI Press World Economic Forum. 2018. The Global Competitiveness Report 2018. 